\title{
Nauczanie języka obcego w grupie uczniów niewidomych i słabowidzących - przegląd badań
}

ABSTRACT: Małgorzata Jedynak, Nauczanie języka obcego w grupie uczniów niewidomych $i$ stabowidzacych - przegląd badań [Teaching a foreign language to partially sighted and blind learners - overview of research findings]. Interdyscyplinarne Konteksty Pedagogiki Specjalnej, nr 21, Poznań 2018. Pp. 207-225. Adam Mickiewicz University Press. ISSN 2300-391X. DOI: https:/ / doi.org/10.14746/ikps.2018.21.11

The paper concerns foreign language typhlomethodology and presents an overview of available research findings in the field, arranged in chronological order. The studies discussed in the paper have insight into either first language acquisition or foreign language learning by visually impaired learners. The former shed light on the potential problems the visually impaired might have while learning foreign languages. The problems might emerge both in the phonological or semantic domain. The latter, in turn, discuss such issues as the use of foreign language vocabulary learning strategies and the role of affective factors which facilitate the language learning process. Nowadays the European Union promotes 'Languages to All' principle, i.e. teaching languages to all groups of learners, regardless of their disabilities and impairments, preferably in inclusive education setting. Therefore, foreign language teachers should be acquainted with the research findings and their implications presented herein.

KEY WORDS: research on foreign language typhlomethodology, native language acquisition, foreign language learning 


\section{Wstęp}

Tyfloglottodydaktyka jest stosunkowo nową dziedziną, która wykorzystuje osiągnięcia takich nauk, jak pedagogika specjalna, zwłaszcza tyflopedagogika, psychologia oraz glottodydaktyka. Przedmiotem badań tyfloglottodydaktycznych są procesy kształcenia językowego uczniów z niepełnosprawnością wzroku oraz przyswajania przez nich wiedzy oraz umiejętności językowych. Znajomość języków obcych stanowi niezbędny element edukacji, który ułatwia uczestnictwo w kulturze i życiu społecznym. Co więcej, znajomość języków obcych pełni kompensacyjne funkcje wobec braku lub osłabienia wzroku, w zakresie deprywacji sensorycznej, psychologicznej, komunikacyjnej, twórczej oraz w zakresie rozrywki ${ }^{1}$. Znajomość języków obcych, szczególnie języka angielskiego, zwiększa przede wszystkich szanse uczniów z niepełnosprawnością wzroku na znalezienie pracy oraz na większą integrację ze środowiskiem osób widzących².

Unia Europejska promuje uczenie się języków obcych przez wszystkich uczniów, bez względu na ich poziom niepełnosprawności, co znalazło odzwierciedlenie $\mathrm{w}$ polityce edukacyjnej $\mathrm{w}$ takich hasłach jak "Edukacja dla wszystkich" czy "Języki dla wszystkich”. Liczne programy i projekty unijne, takie jak Eurochance, Listen and Touch, Per Linguas Mundi ad Laborem, LangSen Project oraz Europejskie Portfolio Językowe dla Niewidomych i Niedowidzących zachęcają osoby słabowidzące i niewidome do nauki języków obcych.

Uczeń z niepełnosprawnością wzroku jest w stanie odnieść sukces $w$ nauce języka obcego, jeśli stworzy mu się odpowiednie warunki do jego rozwoju językowego, tzn. zastosuje odpowiednie metody nauczania oraz dostosuje się materiały dydaktyczne do jego potrzeb. Nauczyciel języka obcego powinien zatem posiadać przy-

1 T.P. Krzeszowski, Niewidomi a języki obce, czyli kilka stów o tyfloglottodydaktyce. "Języki Obce w Szkole”, Wydanie specjalne 7: Nauczanie języków obcych uczniów niepetnosprawnych. Ośrodek Rozwoju Edukacji, Warszawa 2001, s. 12.

${ }^{2}$ H. Aikin Araluce, Teaching English as a foreign language to blind and visually impaired young learners: the affective factor. Praca doktorska na Universidad de Castilla-La-Mancha, Cuenca w Hiszpanii, 2005, s. 5. 
najmniej podstawową wiedzę tyfloglottodydaktyczną oraz wiedzę z zakresu nabywania pierwszego i obcego języka przez osoby z niepełnosprawnością wzroku.

W niniejszym artykule dokonuję opisowo-krytycznej analizy dostępnych źródeł tyfloglottodydaktycznych i tyflojęzykoznawczych z zakresu nauczania języka obcego w grupie uczniów niewidomych i słabowidzących.

\section{Początek zainteresowań nauczaniem języków obcych}

Początek zainteresowań nauczaniem języków obcych w środowisku osób słabowidzących i niewidomych przypada na lata 30. ubiegłego wieku. W roku 1931 niewidomy nauczyciel - William Patrick Morrissey - wydał Nauczanie języków obcych w szkołach dla niewidomych. Była to pierwsza publikacja, która zwróciła uwagę na potencjał osób niewidomych do uczenia się języków obcych. Morrisey twierdzi w niej, że utrata wzroku otwiera przed niewidomym uczniem nowe możliwości, gdyż potrafi on w większym stopniu od ucznia widzącego wykorzystać swoje zdolności słuchowe. W swojej publikacji Morrisey zauważa również, że nauka języka obcego opiera się przede wszystkim na zmyśle słuchu, natomiast wzrok, chociaż bardzo przydatny $\mathrm{w}$ nauce, nie jest determinantem sukcesu w nauce języka obcego. Co ciekawe, już w latach 30. ubiegłego wieku pojawił się pogląd o predyspozycjach osób niewidomych do zawodu nauczyciela, a w szczególności nauczyciela języka obcego. W 1934 r. pojawiła się publikacja Jamsa L. Flooda zatytułowana Wartość łaciny w szkołach dla niewidomych, która wskazywała na potrzebę zastosowania $\mathrm{w}$ szkołach dla niewidomych programu nauczania języka łacińskiego powszechnie stosowanego w szkołach ogólnodostępnych. Warto zaznaczyć, że w latach 30. XX w. dominował transmisyjny model nauczania języka obcego oparty na metodzie gramatyczno-tłumaczeniowej i eksplicytnej instrukcji. Programy nauczania języka obcego nie akcentowały zatem potrzeby komunikacji i rozwijania umiejętności mówienia, ale zapamiętywa- 
nia form gramatycznych i rozwijania umiejętności tłumaczenia pisemnego, głównie z języka obcego na język rodzimy, a rzadziej odwrotnie. Pogląd Flooda na temat programów nauczania został entuzjastycznie przyjęty na XXXII Konwencji Amerykańskiego Stowarzyszenia Instruktorów Osób Niewidomych.

\section{Metoda audiolingwialna w nauczaniu języków obcych}

W latach 60. XX w. nauczanie języków obcych uległo transformacji. Pod wpływem behawiorystycznych poglądów rozwinęła się metoda audiolingwialna, która za cel nauki uznaje opanowanie czterech umiejętności językowych $\mathrm{w}$ kolejności od słuchania i mówienia do czytania i pisania. Istotą tej metody jest wykształcenie odpowiednich nawyków językowych, polegających na bezrefleksyjnym i zautomatyzowanym wielokrotnym powtarzaniu, zapamiętywaniu i utrwalaniu materiału językowego ${ }^{3}$. Metoda ta była wykorzystywana w szkołach dla niewidomych oraz na kursach językowych zorganizowanych dla osób z niepełnosprawnością wzroku. Wprawdzie nie istnieją żadne publikacje naukowe na temat efektywności wdrażania tej metody w szkołach, ale istnieje Raport Dosterta z lat 60., który wskazuje na dużą efektywność metody audiolingwialnej w uczeniu języka obcego na kursach językowych. Profesor Dostert z Centrum Badawczego Georgetown nadzorował pierwszą inicjatywę podjętą w USA przez Biuro Narodowej Rehabilitacji w celu przygotowania osób słabowidzących i niewidomych do uczenia się języka obcego, a następnie do zdobycia kwalifikacji do nauczania go w szkołach. Program zakładał, że słuchacze eksperymentalnych kursów nie tylko będą uczyć się języków obcych, ale również rozszerzą swoją wiedze na temat efektywnych metod i technik uczenia się języka przez osoby słabowidzące i niewidome. Słuchaczami kursu były osoby z różnymi niepełnosprawnościami wzrokowymi, pochodzące z różnych amerykańskich stanów. Kurs językowy miał intensywny charakter i obej-

${ }^{3}$ H. Komorowska, Metodyka nauczania jezzyków obcych, Fraszka Edukacyjna, Warszawa 2004, s. 22. 
mował 40 godzin tygodniowo. Podczas kursu wprowadzano typowe techniki dla metody audiolingwialnej, takie jak powtarzanie i uczenie się na pamięć dialogów oraz reagowania w określony sposób na pytania rozmówcy. Zajęcia odbywały się zarówno w klasie, jak i laboratorium językowym, w którym słuchacze mogli uczyć się samodzielnie, odsłuchując nagrania na kasetach i powtarzając zwroty językowe. $\mathrm{Na}$ kursie słuchacze mogli rozwijać wszystkie aspekty języka, aczkolwiek kolejność ich wdrażania była ściśle ustalona i odbiegała od współczesnych podejść do nauczania języka obcego. Przed wprowadzeniem słownictwa i gramatyki języka obcego, słuchacze najpierw zapoznawali się z systemem fonetycznym tego języka, poznając takie zagadnienia, jak artykulacja poszczególnych samogłosek i spółgłosek oraz kombinacji głosek. Jeśli chodzi o umiejętności językowe, to kurs rozwijał przede wszystkim umiejętność słuchania i mówienia z wykorzystaniem gotowych fraz językowych. Umiejętności pisania i czytania były również rozwijane z wykorzystaniem alfabetu Braille'a. W przypadku kursów języka rosyjskiego słuchacze musieli również opanować zapis brajlowski w cyrylicy 4 .

Warto zauważyć, że amerykański projekt Georgetown jako pierwszy na świecie zwrócił uwagę na nowe możliwości zatrudnienia osób z niepełnosprawnością wzroku. Zgodnie z oczekiwaniami jego twórców projekt został uwieńczony sukcesem; po dwóch latach uczestnicy projektu uzyskali kwalifikacje do pracy w charakterze tłumaczy symultanicznych języka niemieckiego i rosyjskiego oraz nauczycieli tych języków. Co więcej, kwalifikacje te przełożyły się na realne zatrudnienie, a większość słuchaczy kursów językowych podjęło pracę w szkołach ogólnodostępnych i specjalnych 5 .

${ }^{4}$ L. Dorstet, The blind learn Russian in Georgetown University, New Beacon, Washington DC, 1963 za: M. Jedynak, Visually impaired learners and selected correlates of their foreign language achievement, Wydawnictwo Uniwersytetu Wrocławskiego, Wrocław 2015, s. 146.

${ }^{5}$ L. Dorstet, The blind learn Russian in Georgetown University, New Beacon, Washington DC, 1963 za: M. Jedynak, Visually impaired learners and selected correlates of their foreign language achievement, Wydawnictwo Uniwersytetu Wrocławskiego, Wrocław 2015, s. 146. 
Inicjatywa podjęta przez amerykańskie Biuro Narodowej Rehabilitacji spowodowała wzrost zainteresowania nauczaniem języka obcego w środowisku osób z niepełnosprawnością wzroku. Katolicka Gildia Niewidomych w Nowym Jorku, zainspirowana projektem Georgetown, wprowadziła pod koniec lat 60 . XX w. innowacyjny program nauczania angielskiego jako języka drugiego dla niewidomych imigrantów. Uczestnicy programu musieli zdeklarować chęć osiedlenia się na stałe w Stanach Zjednoczonych oraz posiadać silną motywację do szybkiego opanowania języka angielskiego. Podobnie jak w projekcie Georgetown, uczestnicy kursu uczyli się języka metodą audiolingwialną. Należy zauważyć, że uczenie skupiało się na przekazaniu praktycznego języka, którego imigranci mogli używać $w$ wielu sytuacjach formalnych oraz nieformalnych poza klasą językową i który pozwalał im na funkcjonowanie w nowym środowisku na poziomie społecznym i zawodowym. Nauczyciel dostarczał słuchaczom kursu odpowiedniego bodźca w formie werbalnej (np. wzoru jakiegoś zdania, początku zdania, pytania, wyrazu sugerującego treść wypowiedzi) lub w formie materiału wizualnego (np. obrazka czy podpisu dostosowanego do potrzeb osób z niepełnosprawnością wzroku) i wielokrotnie powtarzał bodziec. Następnie uczestnicy kursu byli proszeni o samodzielne powtarzanie bodźca, któremu towarzyszyło wzmocnienie ze strony nauczyciela $\mathrm{w}$ formie pochwały, co gwarantowało sprzężenie zwrotne. Imigranci uczestniczący $\mathrm{w}$ programie musieli więc nie tylko wielokrotnie powtarzać po nauczycielu wzory zdań, ale również wykazać się bardzo dobrymi umiejętnościami zapamiętywania ich. Warto zaznaczyć, że język ojczysty imigrantów nie był wykorzystywany podczas zajęć, aby wyeliminować wszelkie myślenie i porównywanie struktur języka angielskiego z językiem ojczystym. Po opanowaniu $\mathrm{w}$ formie ustnej różnorodnych struktur językowych, uczestnicy kursu musieli przyswoić materiał z zakresu angielskiego Braille'a oraz mowy ciała i mikroekspresji stosowanej przez osoby widzące ${ }^{6}$.

${ }^{6} \mathrm{M}$. Jedynak, Visually impaired learners and selected correlates of their foreign language achievement. Wydawnictwo Uniwersytetu Wrocławskiego, Wrocław 2015, s. 146. 


\section{Badania nad przyswajaniem ojczystego języka i implikacje do nauczania języka obcego}

Lata 60., 70. i 80. ubiegłego wieku to okres bardzo intensywnych badań nad nabywaniem języka ojczystego przez niewidome dzieci Publikacje naukowe, które pojawiły się w tamtych latach pozwoliły nie tylko zrozumieć procesy poznawcze zachodzące $u$ niewidomych dzieci przyswajających ojczysty język, ale również procesy związane z uczeniem się i nauczaniem języków obcych. Anne E. Mills ${ }^{8}$, na przykład, zauważyła, że rozwój fonologiczny $\mathrm{u}$ dzieci niewidomych odbiega nieznacznie od rozwoju fonologicznego $u$ dzieci widzących np. te pierwsze nie widząc miejsca artykulacji dźwięku np. /n/, często zastępują go dźwiękiem o zupełnie innym miejscu artykulacji; podczas gdy widzące dzieci zastępują dźwięk /n/ innym dźwiękiem wargowym tzn. /m/, sugerując się przy produkcji tym samym miejscem artykulacji dla dwóch dźwięków. Powyższa obserwacja może implikować pewne problemy fonologiczne w przypadku uczenia się języka obcego przez niewidome dzieci, ale już niekoniecznie przez dorosłych, którzy najczęściej mają opanowane strategie uczenia się nieznanych dźwięków. Warto zatem poświęcić więcej czasu na lekcji języka obcego na ćwiczenie problematycznych dźwięków, których miejsce artykulacji lub sposób artykulacji może być szczególnie trudny do uchwycenia przez niewidomego ucznia9. Wyniki badań nad rozumieniem pojęć

${ }^{7}$ Np. S. Fraiberg, Insights from the Blind. Basic Books, New York i St Louis, Missouri Blind, 1977; A.E. Mills, The development of phonology in the blind child, [w:] Hearing by Eye: The Psychology of Lip-Reading, red. B. Dodd i R. Campbell, Lawrence Erlbaum Associates, London 1983, s. 145-163.

8 A.E. Mills, The development of phonology in the blind child, [w:] Hearing by Eye: The Psychology of Lip-Reading, red. B. Dodd i R. Campbell, Lawrence Erlbaum Associates, London 1983, s. 145-163, za: M. Jedynak, Visually impaired learners and selected correlates of their foreign language achievement, Wydawnictwo Uniwersytetu Wrocławskiego, Wrocław 2015, s. 132-133.

${ }^{9} \mathrm{M}$. Jedynak, Wptyw nabywania jezyka pierwszego przez niewidome dzieci na nauke języka drugiego - implikacje dydaktyczne dla nauczycieli języków obcych, [w:] PLEY, Psy- 
oraz prototypami w języku ojczystym również dostarczają nauczycielom wiele wskazówek jak efektywnie nauczać języka obcego w grupie uczniów niewidomych. Anne Dunlea ${ }^{10}$ stwierdza, że brak wzroku od urodzenia powoduje, że interpretacja pojęć u osób niewidomych może odbiegać od interpretacji u osób widzących. Dunlea udowodniła, że ci pierwsi, mając ograniczony dostęp do namacalnych lub wizualnych cech obiektów ze świata zewnętrznego, mają problem z pojęciami nieabstrakcyjnymi oraz z generalizowaniem pojęć. Obserwacje te zostały potwierdzone przez wyniki badań Jedynak ${ }^{11}$, w których niewidomi dorośli mieli problem z dokładnym opisaniem pojęć, a ich interpretacja pojęć i zjawisk różniła się nieznacznie od interpretacji osób widzących (np. księżyc był opisywany przez jedną z badanych osób jako obiekt, który ma zawsze ten sam okrągły kształt, a pojęcie bitwa nie oznacza udziału w niej koni). Powyższe wyniki pozwalają przewidzieć pewne problemy $\mathrm{z}$ rozumieniem pojęć, które mogą pojawić się na zajęciach z języka obcego. Dlatego nauczyciel języka obcego powinien najpierw upewnić się, czy i w jaki sposób uczeń niewidomy interpretuje dane pojęcie, tak aby nie było negatywnej interferencji znaczenia z ojczystego języka do języka obcego. W miarę możliwości nauczyciel powinien wprowadzać słownictwo w języku obcym przy pomocy realiów (prawdziwych przedmiotów np. owoce), modeli przestrzennych (np. miniatura księżyca w różnych fazach) lub poprzez połączenie technik dotykowych i słuchowych (np. model psa i odtwarzany dźwięk produkowany przez psa). Niektóre pojęcia, które nie mogą być doświadczone przez dotyk lub słuch (np. kolory) powinny być wprowadzane w języku obcym w formie fraz językowych (np. zielona trawa/green grass, niebieskie niebo/blue sky).

choLingwistyczne Eksploracje Jezykowe, red. O. Majchrzak, Wydział Filologiczny Uniwersytetu Łódzkiego, Łódź 2014, s. 39-55.

10 A. Dunlea, Vision and the emergence of meaning blind and sighted children's early language, Cambridge University Press, Cambridge 1989.

${ }^{11}$ M. Jedynak, Jezykowe odwzorowanie rzeczywistości przez niewidomych $i$ widzących użytkowników języka polskiego. „Rozprawy Komisji Językowej” XXXVIII, Wrocławskie Towarzystwo Naukowe, Wrocław 2011, s. 61-73. 
Badania nad prototypami również pokazują, że niewidome osoby przypisują prototypowość do innych pojęć niż osoby widzące. W badaniu Jedynak ${ }^{12}$ wzięło udział 18 osób niewidomych i 18 widzących w wieku 17-22 lat. W zadaniach testowych badani musieli podać najbardziej prototypowe skojarzenia do słów z ośmiu kategorii (ptak, mebel, owoc, ubiór, pogoda, sport) oraz uszeregować różne słowa w ośmiu kategoriach, zaczynając od najbardziej prototypowego przedstawiciela danej kategorii (np. w kategorii ptak: gołąb, wróbel, łabędź, kaczka, sroka). Rozbieżności w przypisywaniu prototypowości w języku ojczystym przez osoby niewidome i widzące implikują pewne modyfikacje procesu dydaktycznego podczas prowadzenia lekcji z języka obcego z uczniami niewidomymi. Ponieważ podręczniki do nauki języków obcych wprowadzają zagadnienia leksykalne w oparciu o prototypy charakterystyczne dla osób widzących, nauczyciel powinien wzbogacić prezentację nowego materiału o słownictwo prototypowe dla osób niewidomych.

Badanie procesu przyswajania przez niewidome dziecko języka ojczystego zainspirowało również Marshalla ${ }^{13}$. Autor zauważył, że nauczyciele, podobnie jak rodzice uczący niewidome dziecko ojczystego języka, muszą dostosować materiały dydaktyczne do niewidomego ucznia, przygotowując dla niego autentyczne przedmioty (ang. realia), poprzez które może doświadczać uczenia się języka obcego w kontekście. Natomiast Tihomir Nikolic w swojej publikacji Nauczanie angielskiego jako jezzyka obcego w szkołach dla niewidomych $i$ stabowidzacych ${ }^{14}$ porównuje osiągnięcia w nabywaniu języka ojczy-

${ }^{12}$ M. Jedynak, Analysis of Mental Lexicon in Sighted and Blind Children on the Basis of Prototypes. Referat wygłoszony na Międzynarodowej konferencji naukowej Koncepcje w edukacji językowej w kontekście regionalnym i europejskim w Jeleniej Górze w dniach 17-18 października 2008.

${ }^{13}$ K.J. Marshall, Teaching English to the blind. The English Bulletin, 5(4). Hong Kong 1968, za: M. Jedynak, Visually impaired learners and selected correlates of their foreign language achievement, Wydawnictwo Uniwersytetu Wrocławskiego, Wrocław 2015, s. 146-147.

14 T. Nikolic, Teaching a Foreign Language in Schools for Blind and Visually Impaired Children, "Journal of Visual Impairment and Blindness” 1987, v81 n2, s. 62-66. 
stego i obcego. Autor stwierdza, że uczniowie z niepełnosprawnością wzroku mogą odnieść sukces w nauce języka obcego, podobnie jak ma to miejsce w nauce ich ojczystego języka. Nikolic zwraca uwagę na fakt, że tego typu uczniowie mają szczególny potencjał do przyswajania języków ze względu na ich wrażliwość słuchową oraz wyjątkowo wyćwiczoną pamięć. Można zatem przypuszczać, że powyższe predyspozycje pomagają w opanowaniu fonetyki i fonologii języka obcego oraz posługiwaniu się gotowymi strukturami językowymi. Nikolic postuluje również, aby uczniowie niewidomi i słabowidzący uczyli się języka obcego razem z uczniami widzącymi, gdyż nie ma żadnych przeciwskazań, aby ci pierwsi byli uczeni według innego programu nauczania. Jeśli chodzi o materiały, z których korzystają nauczyciele języków obcych, to powinny one być dostosowane w taki sposób, aby uczeń mógł wykorzystywać resztki wzroku lub używać innych zmysłów kompensujących utratę wzroku.

W latach 80. metoda audioligwialna nie była już tak popularna i metodycy zaczęli zwracać większą uwagę na rozwijanie umiejętności pisania. Dlatego Nikolic podkreśla w swojej publikacji, że umiejętności pisania i czytania w Brajlu w pierwszym języku powinny być traktowane priorytetowo, gdyż warunkują one późniejsze opanowanie tych umiejętności w Brajlu w języku obcym. Autor zwraca również uwagę na fakt, że chociaż biegłość w Braille’u w języku ojczystym przekłada się również na biegłość w języku obcym, to uczniowie mogą mieć problemy z niektórymi podwójnymi symbolami, tzn. takimi, które mogą mieć różne znaczenia w języku ojczystym i obcym. Podobny punkt widzenia ma Holly Guinan ${ }^{15}$, który twierdzi krytycznie, że zajęcia językowe nie mogą opierać się tylko na tradycyjnej metodzie audiolingwialnej rozwijającej głównie słuchanie i mówienie, tylko dlatego że uczeń jest pozbawiony wzroku. Guinan dochodzi do wniosku, że drugorzędne traktowanie umiejętności pisania i czytania w języku obcym wynika przede wszystkim z braku

${ }^{15} \mathrm{H}$. Guinan, ESL for students with visual impairments. "Journal of Visual Impairment and Blindness" 1997, nr 91, s. 555-564. 
kompetencji nauczycieli języków obcych, którzy nie znają wcale lub w bardzo minimalnym stopniu opanowali Braille'a. W konsekwencji wielu uczniów niewidomych ma problemy z prawidłowym przeliterowaniem i zapisem obcojęzycznych słów, a w szczególności słów angielskich. Guinan postuluje, aby nauczyciele języków obcych szkolili się z zakresu edukacji osób z niepełnosprawnością wzroku.

\section{Rola języków obcych we współczesnym świecie}

Ostatnie dwie dekady to okres wielu zmian w edukacji językowej zainspirowane polityką inkluzyjną oraz hasłami równościowymi wyrażonymi w inicjatywach Edukacja dla Wszystkich i Język dla Wszystkich. Wielu badaczy podkreśla ogromną rolę języków obcych w kształtowaniu osobowości i przygotowaniu do aktywności zawodowej16. Słabowidzący i niewidomi absolwenci kierunków filologicznych znajdują pracę w zawodzie nauczyciela języka obcego, tłumacza symultanicznego lub pisemnego. Nauka języka obcego kompensuje utratę wzroku pomagając uczniowi zintegrować się ze społeczeństwem oraz wpływa pozytywnie na jego strukturę psychiczną (poczucie wartości, niezależność). Uczeń z niepełnosprawnością wzroku posiadający kompetencje językowe, szczegól-

${ }^{16}$ B. Marek, 2000a. Teaching visually impaired students in Poland, Online interview, http://www.unicef.org/teachers/forum/0300.htm [dostęp: 9.01.2018]; B. Marek, 2000b. Visions and strategies for the new century. Materiały pokonferencyjne z Konferencji Europejskiej, Kraków 9-13 lipiec 2000, http://www.hungryfingers.com/ learning.html [dostęp: 5.01.2018]; P. Krzeszowski, Niewidomi a języki obce, czyli kilka słów o tyfloglottodydaktyce. "Języki Obce w Szkole”, Wydanie specjalne 7: Nauczanie języków obcych uczniów niepetnosprawnych. Ośrodek Rozwoju Edukacji, Warszawa 2001, s. 5-12; H. Aikin Araluce, Teaching English as a foreign language to blind and visually impaired young learners: the affective factor, Praca doktorska na Universidad de Castilla-La-Mancha, Cuenca w Hiszpanii 2005; K. Czerwińska, Jezzyki obce a osoby $z$ dysfunkcja wzroku. Publikacja z funduszy projektu Per lingua mundi ad laborem. Wydawnictwo Akademii Pedagogiki Specjalnej, Warszawa 2008; B. Wyszyńska, Teaching English as a foreign language to the visually impaired, A re-charged Direct Method, Nieopublikowana praca doktorska, Akademia Nauk w Łodzi 2013. 
nie z języka angielskiego, jest również bardziej atrakcyjny na unijnym rynku pracy ${ }^{17}$. Hilary $\mathrm{McColl}^{18} \mathrm{w}$ swojej publikacji Jezzyki nowożytne dla wszystkich również wskazuje na korzyści wynikające z uczenia się języka obcego. Według autorki potrzeba komunikowania się z ludźmi na całym świecie stanowi ogromną motywację do nauki języka obcego przez osoby zarówno pełnosprawne jak i niepełnosprawne. Co więcej, autorka twierdzi, że niepełnosprawne osoby mogą odnieść sukces w nauce języka obcego, jeśli stworzy się im odpowiednie warunki i możliwości oraz odpowiednio zostaną zmotywowane. McColl uważa, że skuteczność nauki języka obcego zależy w dużej mierze od nauczycieli i tego, w jaki sposób wydobędą z ucznia niepełnosprawnego jego potencjał.

Helena Aikin Araluce ${ }^{19}$ również zwraca uwagę na rolę nauczyciela w nauce języka obcego. W swojej publikacji poświęconej uczeniu języka angielskiego w Hiszpanii prezentuje wyniki badania, które wskazują, że sukces niewidomych dzieci młodszych jest możliwy, jeśli dokona się odpowiedniej adaptacji materiałów dydaktycznych, np. fiszki z obrazkami i podpisami, powszechnie wykorzystywane na zajęciach językowych w celu wprowadzenia nowych elementów leksykalnych, są dostosowane poprzez zastosowanie grafiki dotykowej. Autorka zwraca również uwagę na potrzebę wprowadzania przez nauczycieli wskazówek werbalnych ułatwiających lokalizację przedmiotów w klasie.

W 2005 r. pojawił się raport Komisji Europejskiej Potrzeby edukacji specjalnej w Europie. Nauczanie i uczenie się języków. Analiza i innowacje. Dokument ten podsumowuje lata badań w obszarze nauczania języka obcego wśród uczniów z różnymi niepełnosprawnościami. W konkluzji raportu znajduje się stwierdzenie na temat roli języka

${ }_{17}$ M. Jedynak, Visually impaired learners and selected correlates of their foreign language achievement, Wydawnictwo Uniwersytetu Wrocławskiego, Wrocław 2015.

${ }_{18} \mathrm{H}$. McColl, Modern languages for all. Entitlement for All Series, David Fulton Publishers, Oxford 2000.

${ }^{19} \mathrm{H}$. Aikin Araluce, Teaching English as a foreign language to blind and visually impaired young learners: the affective factor, Praca doktorska na Universidad de Castilla-La-Mancha, Cuenca w Hiszpanii 2005, s. 81. 
obcego w szkolnictwie specjalnym: Uczenie się języka obcego rozwija umiejętności potrzebne do życia oraz dostarcza narzędzi wspomagających rozwój osobowościowy oraz społeczny ${ }^{20}$.

\section{Badania nad podniesieniem efektywności uczenia języka obcego}

Ostatnie dwie dekady to również okres intensywnych poszukiwań sposobów podniesienia efektywności nauczania języka obcego w środowisku uczniów z niepełnosprawnością wzroku. Beata Wyszyńska ${ }^{21} \mathrm{w}$ swojej pracy doktorskiej wskazuje na potrzebę nauczania języka obcego z wykorzystaniem podejścia holistycznego. W przeprowadzonym przez nią badaniu $\mathrm{w}$ grupie uczniów $\mathrm{z}$ niepełnosprawnością wzroku, autorka wdrożyła eksperymentalną metodę nauczania języka obcego nazwaną Psychojęzykowa terapia - Dotykanie świata, w której kompetencje językowe są rozwijane równocześnie z pokonywaniem emocjonalnych zahamowań ucznia. Powyższa metoda dotyczy zatem zarówno warstwy językowej, jak i emocjonalnej. Język jest rozwijany dwutorowo, tzn. leksyka i gramatyka są wprowadzane równocześnie poprzez metodę bezpośrednią (ang. direct method) oraz z wykorzystaniem takich elementów, jak piasek, woda oraz różnorodnych technik rozwijających percepcję słuchowo-dotykową. Opisana metoda wspomaga również rozwój emocjonalny ucznia poprzez zastosowanie Metody B.S.M. bioemanacyjnego sprzężenia ciała z mózgiem (ang. Brain Linkage Method) i elementów wykorzystywanych w psychoterapii, takich jak technika sandtray czy kontrola oddychania. Wyniki badań Wyszyńskiej wskazują na wysoką skuteczność powyższej eksperymentalnej metody uczenia

${ }^{20}$ Komisja Europejska. Raport. Special Educational Needs in Europe. The Teaching and Learning of Languages. Insights and Innovation. Teaching Languages to Learners with Special Needs, DG EAC 2303 LOT 3, 2005, s. 142.

${ }^{21}$ B. Wyszyńska, op. cit. 
języka obcego. Autorka zaobserwowała nie tylko wzrost kompetencji językowych u dzieci z niepełnosprawnością wzroku, ale również wzmocnienie ich poczucia samorealizacji i poczucia wartości. Wyszyńska twierdzi, że to właśnie połączenie $w$ jej eksperymentalnej metodzie elementów języka z elementami psychoterapii pozwala dzieciom osiągnąć tak dobre wyniki z języka obcego.

Jedynak ${ }^{22}$, podobnie jak Wyszyńska, zauważa potrzebę włączenia elementów psychoterapii do nauki języka obcego. Autorka twierdzi, że brak podręczników do nauki języków obcych oraz materiałów dydaktycznych w powiększonym druku i Brajlu oraz niedoświadczeni nauczyciele języków obcych wpływają na emocje ucznia z niepełnosprawnością wzroku. Co więcej, w odróżnieniu od ucznia widzącego uczeń słabowidzący lub niewidomy posiada zupełnie inną strukturę afektywną, w której bardzo często mogą dominować niepewność i lęk, niskie poczucie wartości, wrodzona bezradność, niska motywacja i autonomia czy zewnętrzne umiejscowienie poczucia kontroli. Niejednokrotnie te negatywne stany emocjonalne charakteryzują tego rodzaju ucznia zanim rozpocznie on naukę języka obcego i towarzyszą mu we wszystkich sytuacjach niezwiązanych bezpośrednio z nauką. Wyniki badania ilościowego i jakościowego (wywiady) przeprowadzonego przez autorkę pozwoliły ustalić, że to czynniki afektywne (niska kompetencja radzenia sobie, niska autonomia, oraz zewnętrzne umiejscowienie poczucia kontroli w przypadku osób niewidomych) powodują, że uczniowie z niepełnosprawnością wzroku osiągają niskie wyniki $\mathrm{w}$ nauce języka obcego. Taki stan rzeczy ma miejsce pomimo tak wielu możliwości oferowanych im $\mathrm{w}$ ramach programów i projektów unijnych oraz ogromnego potencjału uczniów słabowidzących i niewidomych do nauki języków obcych. Wnioski z badania trzech korelatów afektywnych zaowocowały stworzeniem afektywnego modelu nauczania języka obcego opartego na psychoterapii. Jego głównym celem jest wskazanie nauczycielom języka obcego, w jaki sposób, oprócz wzmacniania kognitywnego potencjału osób słabo-

${ }^{22}$ M. Jedynak, op. cit. 
widzących i niewidomych, można przyczynić się do poprawy wyników w nauczaniu tego typu uczniów. Model ten opiera się na założeniach edukacji afektywnej, zgodnie z którą najpierw należy rozwinąć osobowość ucznia (jego emocje, postawy, system poglądów), a dopiero później skupiać się na uczeniu tradycyjnych przedmiotów. Zaproponowany model wpisuje się w nurt edukacji humanistycznej i pozytywnej psychologii. Składa się on z trzech etapów: 1) oceny stanu emocjonalnego ucznia przez nauczyciela języka obcego za pomocą takich narzędzi, jak konsultacja z psychologiem szkolnym, zaświadczenia z poradni pedagogiczno-psychologicznej, raporty medyczne, indywidualne programy edukacyjno-terapeutyczne (IPET) opracowane dla ucznia, obserwacje wychowawców i członków rodziny ucznia; 2) opracowania przez nauczyciela języka obcego indywidualnego planu strategicznego skupiającego się na negatywnych stanach afektywnych hamujących efektywne uczenie się języka obcego; 3) wdrożenia do standardowego programu nauczania języka obcego odpowiednich ćwiczeń językowych uzupełnionych o strategie psychoterapeutyczne (np. techniki gier dramatycznych i psychodramy, wzmacniające poczucie wartości).

Sukces w nauce języka obcego zależy również od umiejętności stosowania strategii uczenia się, w tym strategii uczenia się słownictwa. Koncepcja strategii uczenia się języka pojawiła się w połowie lat 70. XX w., ale została rozpowszechniona później dzięki publikacjom takich wiodących badaczy jak Jane Rubin²3, J. Michael O'Malley i in. ${ }^{24}$, a w szczególności Rebecca Oxford ${ }^{25}$. Wyniki ich badań zainspirowały również badania nad strategiami u osób z niepełnosprawnością wzroku. Agata Wesołowska i Małgorzata

${ }^{23}$ J. Rubin, What the good language learner can teach us, TESOL Quarterly, 1981, nr 9: 1, s. 41-51.

24 J.M. O'Malley, A. Chamot, G. Stewner-Manzanares, L. Kupper, R. Russo, Learning strategies used by beginning and intermediate ESL students, "Language Learning", 1985, 35/1, s. 21-46.

${ }^{25}$ R. Oxford, Language learning strategies: What every teacher should know, USA: Newbury House, New York 1990. 
Jedynak ${ }^{26}$ postanowiły zbadać wpływ utraty wzroku na wybór strategii uczenia się języka angielskiego u młodzieży gimnazjalnej i licealnej na średniozaawansowanym poziomie (B1, B1+). Analiza komparatywna trzech grup uczniów (tzn. grupy uczniów niewidomych i ociemniałych, grupy uczniów słabowidzących oraz grupy uczniów widzących) pokazała, że trzy grupy różnią się w stosowaniu strategii, chociaż występują grupy strategii stosowane przez wszystkich uczniów. Procedura badawcza wykorzystywała technikę wywiadu retrospektywnego, podczas którego uczestnicy badania musieli wypowiedzieć się na temat strategii, które stosowali przy nauce następujących kategorii leksykalnych: rzeczowników abstrakcyjnych, idiomów, wyrażeń przyimkowych oraz rekcji czasowników z przyimkami. Aby zachęcić badanych do opisania sytuacji/kontekstu, w którym nauczyli się danej kategorii leksykalnej zastosowano również elementy wywiadu otwartego. Respondenci mogli opisać strategię, dzięki której zapamiętali daną kategorię leksykalną podaną im przez badaczy, wskazać na znajomość danej kategorii leksykalnej lub wskazać na brak znajomości strategii. Odpowiedzi respondentów zostały zaklasyfikowane jako K (ang. known before - znane wcześniej), 0 (ang. do not remember - nie pamiętam), I Strategia Słowa Kluczowego (ang. keyword), II Strategia używania wyobraźni (z ang. using imagery), III Strategia zapamiętywania poprzez dźwięku (ang. representing sounds in memory), IV Strategia zastosowania ruchu (ang. employing action), V Strategia skojarzeń (ang. mental associations). Wyniki badania pokazały, że istniały statystycznie istotne różnice pomiędzy grupami, a mianowicie:

- widzący uczniowie stosowali częściej od innych grup strategie z grupy I,

- słabowidzący uczniowie stosowali częściej od innych grup strategię III, oraz

${ }^{26}$ A. Wesołowska, M. Jedynak, FL Vocabulary Learning Strategies Used by Blind, Partially Blind and Normally Sighted Learners of English In Teaching Languages off the Beaten Track, [w:] Language Learning \& Language Teaching series, red. M. Paradowski, Peter Lang, Frankfurt am Main 2014, s. 306-328. 
- niewidomi uczniowie stosowali częściej od innych grup strategie $\mathrm{V}$.

Powyższe wyniki mogą sugerować, że nauczyciele języków obcych powinni nie tylko pomagać uczniom niewidomym i słabowidzącym rozwijać strategie słowa kluczowego, powszechnie stosowane przez osoby widzące, ale również rozwijać strategie zapamiętywania słów poprzez dźwięk oraz strategie zapamiętywania poprzez skojarzenia. Warto wspomnieć w tym miejscu o projekcie LANGLEARN-L realizowanym na platformie, który pozwala osobom słabowidzącym i niewidomym, ich rodzicom oraz nauczycielom na wymianę doświadczeń oraz zapoznanie się ze strategiami uczenia się języka ojczystego i obcego przez osoby z niepełnosprawnością wzroku.

\section{Podsumowanie}

Nauczyciel języków obcych, który pracuje z uczniem słabowidzącym lub niewidomym, powinien dysponować nie tylko wiedzą merytoryczną z zakresu języka obcego, ale również tą związaną z nabywaniem języka pierwszego i obcego przez osoby niepełnosprawne wzrokowo. Przegląd badań zaprezentowany w niniejszym artykule pokazuje, że nauczyciel nie powinien ograniczać się do stosowania metody audiolingwialnej rozwijającej głównie sprawności słuchania i mówienia w języku obcym, ale również rozwijać sprawności językowe, takie jak czytanie i pisanie. Nauczyciel powinien także rozwijać wszystkie aspekty języka obcego takie jak gramatyka, fonetyka i słownictwo. Nie ma żadnych przeciwwskazań do wprowadzania słownictwa $w$ języku obcym, nawet jeśli odnosi się ono do pojęć doświadczanych przez kanał wzrokowy. Warto jednak zawsze upewnić się, czy uczeń niewidomy prawidłowo interpretuje dane pojecie w języku ojczystym. Nauczyciel powinien mieć świadomość, jak istotną rolę $\mathrm{w}$ procesie nabywania języka pełnią emocje oraz że można połączyć proces dydaktyczny z elementami psychoterapii, co gwarantuje lepsze osiągnięcia $\mathrm{w}$ nauce języka obcego. 


\section{Bibliografia}

Aikin Araluce H., Teaching English as a foreign language to blind and visually impaired young learners: the affective factor, Praca doktorska na Universidad de Castilla-La-Mancha, Cuenca w Hiszpanii 2005.

Czerwińska K., Języki obce a osoby z dysfunkcja wzroku. Publikacja z funduszy projektu Per lingua mundi ad laborem, Wydawnictwo Akademii Pedagogiki Specjalnej, Warszawa 2008.

Dorstet L., The blind learn Russian in Georgetown University, New Beacon, Washington DC 1963.

Dunlea A., Vision and the emergence of meaning blind and sighted children's early language. Cambridge University Press, Cambridge 1989.

Flood L.J., The value of Latin in schools for the blind, Referat przedstawiony na 32 Konwencji Amerykańskiego Stowarzyszenia Nauczycieli Osób Niewidomych 1934.

Fraiberg S., Insights from the Blind. Basic Books, New York i St Louis, Missouri Blind 1977.

Guinan H., ESL for students with visual impairments. "Journal of Visual Impairment and Blindness" 1997, nr 91, s. 555-564.

Jedynak M., Analysis of Mental Lexicon in Sighted and Blind Children on the Basis of Prototypes, Referat wygłoszony na Międzynarodowej konferencji naukowej Koncepcje w edukacji językowej w kontekście regionalnym i europejskim w Jeleniej Górze w dniach 17-18 października 2008.

Jedynak M., Jezzykowe odwzorowanie rzeczywistości przez niewidomych $i$ widzacych użytkowników języka polskiego. „Rozprawy Komisji Językowej” XXXVIII, Wrocławskie Towarzystwo Naukowe, Wrocław 2011, s. 61-73.

Jedynak M., Wpływ nabywania języka pierwszego przez niewidome dzieci na naukę języka drugiego - implikacje dydaktyczne dla nauczycieli języków obcych, [w:] PLEY, PsychoLingwistyczne Eksploracje Jezzykowe, red. O. Majchrzak, Wydział Filologiczny Uniwersytetu Łódzkiego, Łódź 2014, s. 39-55.

Jedynak M., Visually impaired learners and selected correlates of their foreign language achievement. Wydawnictwo Uniwersytetu Wrocławskiego, Wrocław 2015.

Komorowska H., Metodyka nauczania języków obcych. Fraszka Edukacyjna, Warszawa 2004.

Komisja Europejska, Raport Special Educational Needs in Europe. The Teaching and Learning of Languages. Insights and Innovation. Teaching Languages to Learners with Special Needs. DG EAC 2303 LOT 32005.

Krzeszowski T.P., Niewidomi a języki obce, czyli kilka słów o tyfloglottodydaktyce. „Języki Obce w Szkole", Wydanie specjalne 7: Nauczanie języków obcych uczniów niepetnosprawnych. Ośrodek Rozwoju Edukacji, Warszawa 2001, s. 5-12.

Marek B., Teaching visually impaired students in Poland. Online interview, 2000a, http:/ / www.unicef.org/teachers/forum/0300.htm [dostęp: 9.01.2018]. 
Marek B., Visions and strategies for the new century. Materiały pokonferencyjne z Konferencji Europejskiej, Kraków 9-13 lipca 2000, 2000b http://www.hungryfin gers.com/learning.html [dostęp: 5.01.2018].

Marshall K.J., Teaching English to the blind. The English Bulletin, 5(4), Hong Kong 1968.

McColl H., Modern languages for all. Entitlement for All Series. David Fulton Publishers, Oxford 2000.

McDonald R., A Report on Special Intensive Language. Courses for the Blind. Georgetown University Institute for Language and Linguistics, Washington DC 1968.

Mills A.E., The development of phonology in the blind child, [w:] Hearing by Eye: The Psychology of Lip-Reading, red. B. Dodd, R. Campbell, London: Lawrence Erlbaum Associates 1983, s. 145-163.

Morrissey W.P., Teaching Foreign Languages in Schools for the Blind. The Teachers Forum, Nov. 1931.

Nikolic T., Teaching a Foreign Language in Schools for Blind and Visually Impaired Children, Journal of Visual Impairment and Blindness, v81 n2, s. 62-66 1987.

O’Malley J.M., Chamot A., Stewner-Manzanares G., Kupper L., Russo R., Learning strategies used by beginning and intermediate ESL students. "Language Learning" $1985,35 / 1$, s. 21-46.

Oxford R., Language learning strategies: What every teacher should know, USA: Newbury House, New York 1990.

Rubin J., What the good language learner can teach us, “TESOL Quarterly" 1981, nr 9: 1, s. $41-51$.

Wesołowska A., Jedynak M., FL Vocabulary Learning Strategies Used by Blind, Partially Blind and Normally Sighted Learners of English In Teaching Languages off the Beaten Track, [w:] Language Learning \& Language Teaching series, red. M. Paradowski, Peter Lang, Frankfurt am Main 2014, s. 306-328.

Wyszyńska B., Teaching English as a foreign language to the visually impaired. A recharged Direct Method, Nieopublikowana praca doktorska, Akademia Nauk w Łodzi 2013. 